\title{
DELIVERY STRATEGY AND MARKETING COMMUNICATION OF TOURISM SERVICES (TOURISM DESTINATION STUDY MUARO JAMBI TEMPLE)
}

\author{
Erida, Yenny Yuniarti, Raja Sharah Fatricia ${ }^{123)}$ \\ ${ }^{123)}$ Faculty of Economics and Business, Universitas Jambi, Jambi, Indonesia \\ Corresponding Author: eau_de_cherie@yahoo.com
}

\begin{abstract}
This study aims: 1). Analyzing consumer perceptions of marketing delivery strategy and marketing communication services run on the object of Muarojambi temple, 2). Analyzing the influence of delivery strategy and communication of tourism service pemsasaran to the tourists interest to visit Muarajambi temple. 3). Recommends marketing delivery strategy and marketing communication services that can be applied in increasing interest and tourist visit to Muarojambi temple. The sample used is the community / tourists who numbered 110 respondents. Analyzer used average score to know perception of society, and multiple linear regression analysis. The results showed that the community / tourists give a positive response to the marketing delivery strategy and communication of tourism destinations Muara Jambi temple. From the results of hypothesis testing, there are significant influence both simultaneously and partially variable delivery strategy and marketing communications to the interests of tourist visits. It should be increased the frequency of attractions, cultural titles / festivals as one of the keys to successfully bringing tourists in Muarajambi, besides the support of other physical facilities. It takes the involvement of all stakeholders in the development of tourism potential and promotion through the choice of effective marketing communication strategy of tourism services to reach the wider market through the utilization of social media / internet, in addition to direct promotion through exhibition and tourism expo.
\end{abstract}

Keywords : Delivery of Services, Marketing Communications, Interest in Tourist Visits

\section{Introduction}

Implementation of the MEA at the end of 2015, poses challenges for Indonesia as an Asean member country. On the one hand, the threat of invasions of Asean member countries' products to the Indonesian market is unavailable, but on the other hand the MEA era is an important momentum for Indonesia to exploit it in expanding its domestic products and services, including the tourism sector. The tourism sector will be the country's largest foreign exchange earner of oil and gas, coal, oil palm and natural rubber (Anonim, 2014). There will be an increase in foreign exchange generated from the tourism sector in 2019.

The tourism industry is a very dynamic and most promising sector. The contribution of the tourism sector to economic growth has become a topic in economic studies and research (Kodrat Wibowo, 2017). The United Nations World Tourism Organization (UNWTO) notes that by 2014 the tourism sector has contributed 9.5\% to global GDP and 5\% to world exports. Research Antonakakis, Dragouni, and Fillis (2014) found a dynamic relationship between the growth of the tourism sector and economic growth, creative industries among them. The tourism sector has proven to provide a boost to other sectors in the economy of a country / region when accompanied by infrastructure development.

Jambi Province holds a lot of tourism potential and creative economy products that can be developed. Some tourist destinations such as, the East Coast Jambi region, with marine tourism potential, Berbak National Park (TNB), and Safar Bath culture. While in the city of Jambi there are peculiarities such as buildings, monuments, bridges, shopping centers, and Seberang Jambi Cultural Heritage area which is crossed the longest river in Sumatra, Batanghari River with its Batik Jambi center. Furthermore, in the district of Merangin, there are geological tourist sites, "Geopark" and rafting. Likewise in Kerinci with the exotic area of Mount Kerinci which in its feet decorated the expanse of tea plantation Aro Woods covering 3,020 hectares, and is the second highest tea plantation in the world after Darjeling tea plantation in Himalayan Foothills of India, and no less interesting is the existence of Muarajambi temple as a site historical relics located in Muaro Jambi regency.

Muara Jambi Temple area is a relic of the Ancient Malay Kingdom, and the only center of worship from the largest Hindu Buddhist period (7-13 AD) in Indonesia, and into the region being fought for into the world heritage site. This area is also supported by the natural and social environment that is still well preserved.

Domestic tourist arrivals to Jambi Province during the last five years fluctuated, the increase in visits occurred for three years from 2012 to 2014, but a sharp decline last two years. While foreign tourists, although the number is still very small, showing the trend of increase during the period $2012-2016$. The number of tourist visits above is still relatively small when compared with the number of tourist visits Jambi Province. During the year 2015 
the number of domestic tourists visiting Jambi amounted to 2.44 million and foreign tourists amounted to 10,776, (Padmasana Foundation, 2017). The number of tourist visits, especially foreign tourists can be said is still too small when compared with the number of foreign tourists visiting nationally. This condition can be caused by the still weak competitiveness of tourism sector of Jambi Province. As a result, the tourism sector of Jambi Province, still not able to become one of the economic support of society and as a contributor to the local revenue.

The great potential of the tourism sector if managed well, including the promotion and development of human resources conducted by local governments and tourism businesses in Jambi Province, will be able to increase the number of tourist visits. The competitiveness of the tourism sector of Jambi will be enhanced by the linkage of tourism destination management with other related sectors in addition to the supporting infrastructure of tourism, namely the existence of creative industries as an important support tourist destination, and support the marketing communication strategy of tourism services.

Formulation of the problem, the management of tourist destinations is linked to how the services are delivered to the service users. Conceptually, there are three main dimensions of tourism service delivery activities (Yoeti, 1985): Something to see is connected with various attractions held in a tourist destination, something to do related to tourist activities in the tourist area, and something to buy linked to the product / souvenirs typical of areas purchased by tourists. How these three dimensions work and are able to attract tourists to visit, also can not be separated from the marketing strategy of tourism travel services run. Based on this matter can be formulated research problem as follow: 1). How is the consumer's perception towards the delivery and marketing communication of tourism services tourist object of Muarajambi temple? 2). How the influence of delivery strategy and marketing communications of tourist services to the interests of tourists visiting the temple Muarajambi? 3 ). How is the marketing and marketing communication strategy of tourism services that can be applied in increasing the interest and tourist visit to Muara Jambi temple?

Research purposes, based on the research problem, then the purpose of this research are:

1. Analyzing consumer perceptions of marketing delivery and marketing strategy of Muaro Jambi temple tourism services

2. Analyzing the influence of delivery strategy and the communication of tourism service pemsasaran to the interest of tourists visiting the temple Muaro Jambi

3. Recommend marketing delivery strategy and marketing communication services that can be applied in increasing interest and tourist visit to Muaro Jambi temple

\section{Literature Review}

Tourist destination is a geographical area located within one or more administrative areas in which there are tourist attractions, public facilities, tourism facilities, accessibility, and interconnected communities and complete the realization of tourism. (Law Number 10 Year 2009 on Tourism). According to Cooper et al (1998), tourist destinations is one of the most important elements because it is the reason people - people to travel and tourist attraction in it will attract tourist visits. An ideal tourist destination is a region that has a unique and characteristic that gives a strong reason for tourists to visit with longer visiting time, and more importantly interest them to return to the tourist attractions.

The delivery of tourism services, services, including tourist services is a package that is an integrated service environment and plays an important role as a form of experience and consumer behavior. The service environment, in particular the physical environment of services is where services are created, where interactions of service providers with consumers, plus any tangible elements used to communicate or support the service's role, (Lupiyoadi, 2013). There are two types of physical environments of services: 1). essential evidence, and 2). supporting evidence (peripheral evidence). These two types of physical environments in the context of tourism services, integrated into the dimensions of tourism activities (Yoeti, 1985) are:

1). Something to see, related to the various attractions that exist in the tourist destination are: a). natural attraction, including Site Attraction, in the form of climate, scenery, flora and fauna, or historical place, and Event Attraction in the form of MICE activities (Meeting, Incentive, Conference, Exhibition), or sporting events such as Olympic, World Cup, - another. b). Cultural attraction: based on human activities such as karapan sapi, ngaben, sekaten, megeret pandan, burial of corpse in Terunyan, and Muarajambi temple festival. c). Special types of attraction: This attraction is not related to the above two categories but is an artificial attraction like theme park, circus, shopping, (Inskeep, 1991):

Marketing communications in general can be interpreted as an effort to deliver a message to the public, especially target consumers about the existence of products on offer to the market. Conceptually, there are three main purposes of marketing communications: a) disseminating information, b). influence to make purchases or attract consumers and c). remind the audience to re-buy. There are six choices of communication service marketing mix (Lovelock, 2005): personal communications, advertising, sales promotion, publicity and public relations, instructional materials, and corporate design. 
Buy Interest, Buying interest is part of the behavioral component in consuming attitudes. According to Kinnear and Taylor (1995), buying interest is the stage of respondent's tendency to act before the buying decision is actually implemented. According to Ferdinand (2002), buying interest can be identified through the following indicators:

1. Transactional interest, namely the tendency of someone to buy the product.

2. Refrensial interest, namely the tendency of someone to reference the product to others.

3. Preferential interest, ie interest that describes the behavior of someone who has a main preference on the product. This preference can only be changed if something happens with its preference product.

4. Interest explorative, this interest describes the behavior of someone who is always looking for information about the products of interest and seek information to support the positive traits of the product.

\section{Research Methods}

Types, sources and techniques of data collection, data used in this research consist of: a). Primary data obtained directly from the respondents, are perceptual related to the variables studied by using observation techniques, interviews and questionnaire distribution, b). secondary data is collected in the form of good institutional reports, literature review, printed publications and internet publications and other scientific journal publications related to research topics

Population and Sample, the population in this study are people / tourists who are not limited by region, and the number is unknown. Determination of the number of samples refers to the number of indicators of research variables. Based on the consideration, the sample size is set at 110 people.

Research variable, the input variables in this study consist of 1). Tourism service delivery strategy (X1), referring to the concept of Yoeti (1985), includes dimensions, a). something to see, related to the various attractions held in the destination, namely natural attraction, cultural attraction, and special types of attraction, b). Something to do, includes various activities undertaken by tourists in tourist destinations c). Something to buy, associated with typical souvenirs purchased in tourist areas as personal memorabilia $\backslash$ tourists. 2). The marketing communication strategy of tourism services (X2), with indicators of choice of mix (Lovelock, 2005) includes: advertising in print and electronic media and the Internet, publicity and public relations, communication materials (Fandy Tjiptono, 2001), namely: brochures, video / audio visual, and content / message content. 3). Interest in tourist visits (Y), the desire of tourists to visit the targeted tourist attraction, is the stage of the tendency of respondents to act before the purchase decision is actually implemented. (Kinnear and Taylor 1995) with Transactional Interests indicators (tend to buy products), Refrential Interests (references to others), preferential interests (main preference) and explorative interest (finding information)

Analysis Technique, this study uses survey approach with the spread of questionnaires conducted online in the hope of obtaining real information about the object of research. the data obtained will be analyzed by: 1). The average score to know the respondent's perception of the research variable's statement, 2). Regression analysis, which is used to measure the influence of strategy variable of marketing service delivery and komuikasi on the interest of visits to tourist destinations.

\section{Result and Discussion}

Description of Respondent's Characteristics, respondents taken in this study amounted to 110 people, Description of the identity of respondents can be described as follows:

Gender and age, distribution of respondents by gender group $60 \%$ percent female sex. This shows the majority of women have a higher interest to fill the holiday with a tour. While based on age, the majority of respondents ie $85 \%$ are in the age range $17-30$ years. This shows that this age group in general is the age group that has a tendency to take advantage of vacation time by traveling.

Education and employment, based on the level of education and occupation, the majority of respondents were drawn, $60 \%$ had high school education, and still had the status of students and students that was $63 \%$. If it is related to the age of respondents, it appears that most respondents are at school age. It is depicted that cultural and historical tourism such as Muarajambi Temple tourist destinations can be an attractive holiday option for teenagers and students, as well as educational media for their history and culture.

Income and frequency of travel, respondents based on the level of income, obtained an illustration that $78 \%$ of respondents who are interested to come to Muarajambi temple area that has income up to Rp.2000.000, -. If it is associated with respondents based on age and occupation that majority are students, going to Muarajambi temple area does not require big cost, so it can be reached. While based on the frequency of travel it is seen that the majority of respondents, $85 \%$ never travel though with a relatively low frequency (sometimes). This does not close the possibility that historical and cultural tours such as tourism destinations Muara Jambi temple become an option for people to vacation like a school holiday.

Participation of Others in Travel, the majority of respondents prefer to travel in groups, either with the nuclear family or with friends and companions with the composition of respondents by $98 \%$. This shows that tourist visits, 
including the potential to visit cultural and historical tourist areas such as Muarajambi temple, can deepen family relationships, and there is good interaction for all family members, as well as in building closeness of friendship. This can be taken into consideration in designing a strategy in marketing the object of Muara Jambi temple.

Media Information used, the majority of respondents obtained information about tourism destinations Muarajambi temple from the internet / social media that is equal to $56 \%$. This is in line with data from koinworks.com that internet users in Indonesia until June 2016 is 88.1 million people, of the total population of Indonesia which is more than 200 million people. It can be argued that the internet / social media is the most effective medium of information and marketing communications that can be used in reaching such a vast market.

\section{Consumer Perceptions}

Submission of Tourist services, based on the results of data on eight indicators of the three dimensions of tourism service delivery, the average score of respondents in the Something to see dimension of 3.87, something to do dimension of 4.08 , and something to buy of 3.71 . It can be said that the respondents gave a positive response to the three dimensions of tourism service delivery, with the highest score given on the dimensions of something to buy. This indicates that the availability of supporting facilities (such as bicycle rental, becak provision, effective as a service component in pampering tourists, allowing visitors to get around enjoying the vast encampment area. including rental mats, pendopo and lesehan huts that visitors can use for leisure, or for other family occasions such as small birthday celebrations, school events, or even other gathering activities that take advantage of the natural and beauty shades and shady trees of the temple.

Marketing Communications, marketing communications play an important role in delivering messages to the public or target consumers regarding the existence of the product. Therefore, marketers must be able to ensure the main purpose of effective communication messages attract the attention of the recipient, and ultimately able to influence consumers to make purchases, in other words can encourage tourists to visit tourist destinations in the context of tourism services marketing.

From the results of data shows that the indicator of marketing communication mix that has the highest average value is the effectiveness of tourism promotion of Muarajambi Temple area through exhibition / expo in regional, national and international event that is equal to 3,99. This shows that with the exhibitions and tourist expo Muarajambi Temple can attract domestic and international tourists to visit. Promotion of tourism through online media occupies the next position with an average score of 3.95. This is in line with the fact that the majority of respondents get information about tourist destinations through online media / social media.

\section{Hypothesis testing}

Simultaneous influence, $\mathrm{F}$ test is used to find out whether the independent variables used in the research have significant effect simultaneously on the dependent variable. This can be seen in the following table:

\section{Tabel 1. Simultaneous Test (F Test)}

\begin{tabular}{|c|c|c|c|c|c|c|}
\hline \multicolumn{7}{|c|}{ ANOVA $^{b}$} \\
\hline & & Sum of Squares & $\mathrm{df}$ & Mean Square & $\mathrm{F}$ & Sig. \\
\hline \multirow[t]{3}{*}{1} & Regression & 1049.216 & 2 & 524.608 & 892.913 & $.000^{\mathrm{a}}$ \\
\hline & Residual & 62.865 & 107 & .588 & & \\
\hline & Total & 1112.081 & 109 & & & \\
\hline
\end{tabular}

a. Predictors: (Constant), Strategi_X2, Jasa_X1

b. Dependent Variable: MInat_Y

From the table above shows that simultaneously independent variables significantly affect the dependent variable because the value of significance is smaller than the value of the degree of trust used is $0,000<0.05$. Then $\mathrm{H} 1$ is accepted and $\mathrm{H} 0$ is rejected. This means that the variable delivery of services, and communication strategies together affect the variables of interest to visit tourist destinations Muara Jambi Temple.

Partial Influence, the $t$ test is used to find out whether the independent variables partially (individually) affect or not affect the dependent variable. This can be seen in the following table:

Table 2. Partial Testing (Uji t) Coefficients ${ }^{a}$

\begin{tabular}{|c|c|c|c|c|c|c|c|c|c|}
\hline \multirow{2}{*}{\multicolumn{2}{|c|}{ Model }} & \multicolumn{2}{|c|}{$\begin{array}{c}\text { Unstandardized } \\
\text { Coefficients }\end{array}$} & \multirow{2}{*}{$\begin{array}{c}\begin{array}{c}\text { Standardized } \\
\text { Coefficients }\end{array} \\
\text { Beta }\end{array}$} & \multirow[b]{2}{*}{$\mathrm{t}$} & \multirow[b]{2}{*}{ Sig. } & \multicolumn{3}{|c|}{ Correlations } \\
\hline & & $B$ & Std. Error & & & & Zero-order & Partial & Part \\
\hline 1 & (Constant) & .888 & .301 & & 2.949 & .004 & & & \\
\hline & Jasa_X1 & .004 & .001 & .438 & 5.454 & .000 & .959 & .466 & .125 \\
\hline & Strategi_X2 & .540 & .080 & .544 & 6.778 & .000 & .963 & .548 & .156 \\
\hline
\end{tabular}


1. Service Delivery (x1) to Visiting Interest

Seen in the table above the significant value at $\mathrm{x} 1$ is 0.000 . This significant value is smaller than probability value 0,05 or value $0,000<0,005$, hence there is significant and positive influence of service variable partially to visitor interest.

2. Communication Strategy (x2) on Visiting Interest

Seen in table 2 the significant value at $\mathrm{x} 2$ is 0.000 . Significant value smaller than probability value 0,05 or value $0,000<0,005$, hence there is significant and positive influence of variable of communication strategy partially to ask visitor.

From the table above shows that partially the service delivery and communication strategy variables significantly influence the variables of interest visiting the tourist destinations Muarajambi Temple, this can be seen from the significance value of both free variables is 0.000 , where the value of significance of both variables is smaller of the degree of confidence of 0.05 . So can be determined research model as follows:

$$
\mathrm{Y}=0,888+0,004 \mathrm{X}_{1}+0,540 \mathrm{X}_{2}+\mathrm{e}
$$

Coefficient of Determination $\left(\mathrm{R}^{2}\right)$, Based on the results of data analysis using computer assistance program SPSS 16.0, it can be explained that the delivery of Services and Communications Strategy influence $94.3 \%$ of visiting interest, while $5.7 \%$ influenced by other variables that are not examined. The figure is considered large, which means the influence of service delivery and marketing communications are so strong in encouraging tourists to visit tourist destinations.

\section{Analysis and Implication Outcomes}

Service Delivery Strategy, referring to the average score of the responses of respondents to the question items related to the delivery of services, obtained positive results. This indicates that the three dimensions of service delivery become an important element in determining the attractiveness of a tourist destination, including the tourist area of Muara Jambi Temple, which is a historical and cultural tourist area. Heritage in the area of Muara Jambi temple has its own value, especially for students and students, and observers of history and culture as a medium of education.

Based on the results of partial statistical tests can be proven the existence of a significant influence of service delivery strategy to the interest of tourists visiting tourist attraction Muarajambi Temple. This indicates that the three dimensions of service delivery in the form of both essential evidence and peripheral evidence become the determinant of tourist concession to tourist destinations, including tourism destinations Muara Jambi Temple. Therefore, various weaknesses related to the management of tourism object Muarajambi Temple, especially associated with supporting facilities in the temple area such as toilets, musholla, entrance post, souvenir shops lined at the entrance, and the parking area that impressed not well laid out can made priority to be addressed immediately. The existence of souvenir shops, the area of the temple arranged with the quality and variety of products offered, of course expected to attract the attention and interest of visitors to buy.

Marketing Communication Strategy, the success of the marketing communication of tourism services depends on how consumers are exposed to information about the product through the chosen communication medium, whether the content of the communication message designed is able to get consumers into it, then understand the meaning of the information received, so that the knowledge generated when integrated with other knowledge is able shape the attitude and encourage the desire to make a purchase, in this case the desire to visit tourist destinations.

Referring to the results of the data, obtained an illustration that the average respondent gave a positive response to the statement related marketing communication variables used. Promotion tour Muarajambi Temple through exhibition activities get the highest response, followed by the use of internet / social media. This is possible because through the exhibition and tourism expo and the use of internet / social media, consumers get more comprehensive and complete information about Muarajambi temple as a historical and cultural tourist destination and is being fought as a national strategic and world heritage site (the world heritage site).

Based on the results of statistical tests show that marketing communication strategy variables convincingly affect the interest of tourist visits. It can be interpreted that marketing communications with all the indicators, such as message design, media used, ease of access and intensity of information become determinants of tourist attraction of a destination, so interested and have a strong intention to visit tourist destinations.

Tourism is a temporary travel activity from the original residence to the destination area for reasons not for settling or earning a living but only for fun, fulfilling curiosity, spending leisure or holiday time and other destination purposes (UNESCO 2009). The success of tourism activities, of course, can not be separated from how tourism services can be enjoyed, and how tourist destinations are communicated so that leads to the occurrence of tourist visits. 
The results showed that the influence of convincing variables of delivery and communication of tourism marketing services to the interest of tourists visiting the tourist attraction Muarajambi Temple. That is, the fulfillment of the three main elements of service delivery, something to see, something to do and something to buy, the communication mix used, the message and the intensity of the information conveyed become the key to success in an effort to increase visits to tourist destinations.

\section{Conclusions and Suggestions}

Conclusions, Based on the results of research analysis can be drawn conclusion:

1. Simultaneously, the independent variables of service delivery and communication strategies together affect the interest of tourists visiting the destination of Muarajambi temple. This shows that the collaboration of variable delivery and marketing communications of tourist services, become determinants of tourists interest to visit Muarajambi temple.

2. Partially, there is a significant influence of service delivery and marketing communication strategy to the interest of visiting the destination of Muarajambi temple. The service delivery strategy with all physical evidence of both essential and peripheral nature integrated into the three dimensions of service delivery, if improved both quantitatively and qualitatively will be able to encourage increased tourist interest. Likewise with marketing communication strategy variables. Selected communication mix, communication message, message delivery media, continuity of information delivery become important determinant of tourist interest to visit tourist destinations Muarajambi temple.

Suggestions, based on the results of the analysis and research findings, the following recommendations can be used as reference:

1. The relation of the physical environment of the delivery in tourist destinations to the three dimensions of service delivery can not be separated. For that required creative space through the oulet arrangement of craft products (souvenirs), including typical culinary tourist areas that are able to attract and bring tourists. The frequency of attractions, titles and cultural festivals that are one of the keys to the success of bringing in tourists, need to be improved, in addition to the physical support of other tourist services such as, clean and adequate parking areas, clean and adequate toilets, musholla. the addition of rental facilities such as bicycles, tricycles, pendopo and cottage lesehan that allows tourists to enjoy and perform a variety of activities that are more varied in tourist destinations.

2. The involvement of all stakeholders, from the central and district governments, the business community and the community in the development of tourism potential and promotion through the choice of effective marketing communication strategies to reach broader markets such as social media / internet utilization, in addition to direct promotion by following exhibitions or tourist expo conducted domestically and internationally.

3. It takes continuity of delivering interesting information on all aspects related to the existence of tourist destinations, the beauty of the natural environment, the ease of access, the facilities provided, the various attractions, festivals and cultural titles held on the communication medium used so as to increase the preferences of tourists to visit.

\section{References}

Anonim, (2014), Siaran pers Menteri Pariwisata dan Ekonomi Kreatif, 18 Maret, 2014 (2009), Undang-Undang Nomor 10 tahun 2009 Tentang Kepariwisataan.

Cooper, et al, (1998), Tourism: Principles and Practices, New York: Longman Publishing.

Fandy Tjiptono, (2007), Pemasaran Strategik, Yogyakarta, Penerbit Andi

Imam Ghozali. (2009), Aplikasi Analisis Multivariate Dengan Program SPSS.Semarang : Badan Penerbit Undip.

Inskeep, Edward, (1991), Tourism Planning: An Integrated and Sustainable Development Approach, Van Nostrand Reinhold, New York.

Kementrian perdagangan Republik Indonesia. (2008), Pengembangan ekonomi kreatif Indonesia 2025,: Rencana pengembangan ekonomi kreatif Indonesia 2009 - 2025

Kodrat, Wibowo (2017), Pariwisata, Kesempatan Kerja, dan Peluang Industri Kreatif, Aplikasi Tabel I-O Jawa Barat 2010

KoinWorks.com/blog/data-pertumbuhan-pengguna-sosial-media-di-Indonesia. 26 Juni 2016.

Lovelock, Christopher, et al, ( 2005), Services Marketing in Asia, People Technology Strategy, Second Edition, Pearson, Prentice Hall

Lupiyoadi, Rambat, (2013), Manajemen Pemasaran Jasa, Berbasis Kompetensi, Edisi 3, Penerbit Salemba Empat

Nurchayati Andalan, (2016), Strategi pengembangan industri kreatif sebagai penggerak destinasi pariwisata di Kabupaten Semarang; Prosiding Seminar Nasional Multi disiplin Ilmu \& Call for paper Unisbank (SENDI U) ke-2, 2016

Ooi, Can Seng, (2006), Tourism and the creative economy in Singapore, 
Pascarini, Ni Nyoman Dewi, (2012), Strategi Komunikasi Pemasaran Pemerintah Daerah Bali, Jurnal Ilmiah Sosiopolitika, Vol.3,No. 2, Juni 2012

UNESCO, (2009), Panduan Dasar Pelaksanaan Ekowisata

Woko Suparwoko, (2015), Pengembangan ekonomi kreatif sebagai penggerak industri pariwisata Kabupaten Purworejo, Jawa Tengah, Publication on Research Gate on 04 March.

Yoeti, Oka A (1985), Pengantar Ilmu pariwisata, Bandung, Penerbit Angkasa 